\title{
Ancient Egyptian Medicine - Investigation Paper
}

\section{Omar M Amin*}

Parasitology Center, Scottsdale, Arizona, USA

*Corresponding Author: Omar M Amin, Parasitology Center, Scottsdale, Arizona, USA

Received: July 12, 2019; Published: October 31, 2019

DOI: 10.31080/ASMI.2019.02.0419

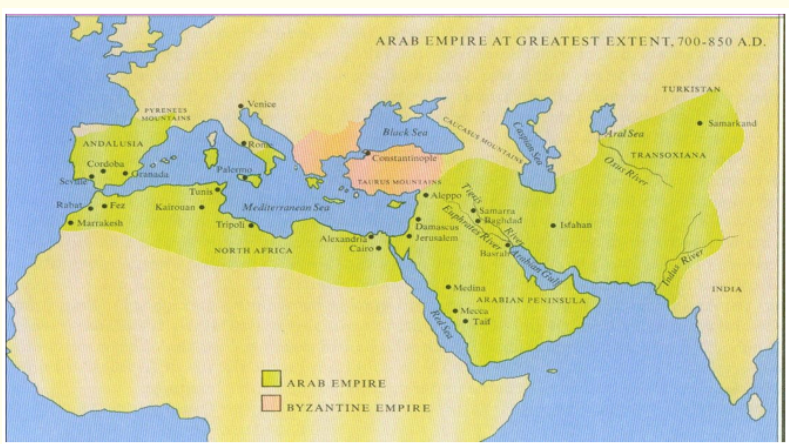

Figure 1

Ancient Egyptian medicine, like other aspects of Egyptian civilization, was a product of the intimate relationship between the heavens and the earth. The bio geometry of life was only a reflection of the heavens.

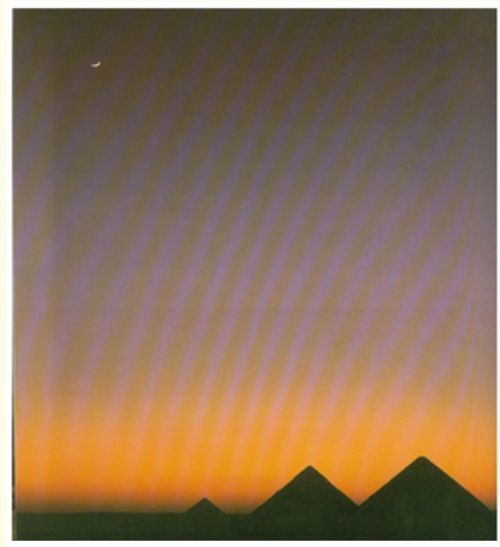

Figure 2
The Nile was only a reflection of the heavenly river, the Milky way.

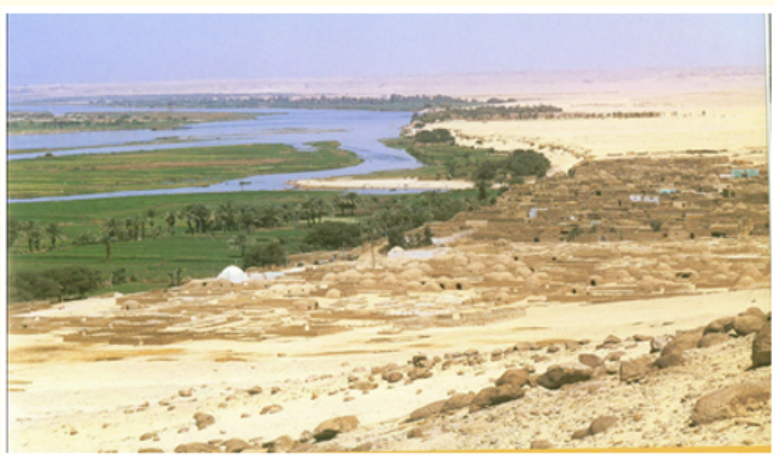

Figure 3

The holy triad of Isis, Osiris and Horus involves the virgin birth, crucifixion and resurrection appeared in Egypt over 5,000 years ago.

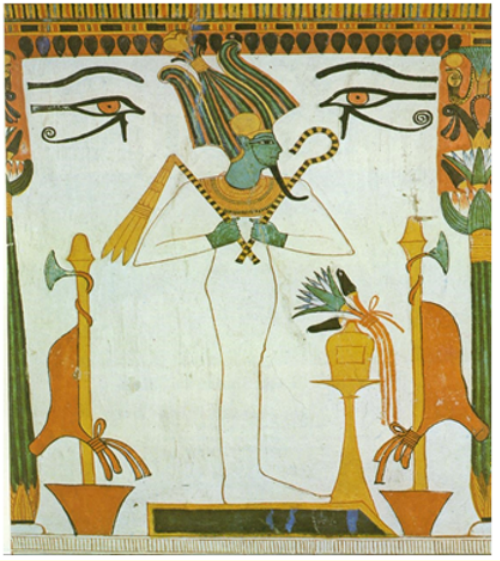

Figure 4 
The Orion constellation which sets and rises daily behind the horizon was the heavenly counterpart of the passing and rebirth of Osiris. The relative size, distance and angle between the 3 great pyramids of Giza are identical to the scale of the 3 major stars of the Orion constellation; a mirror image of the heavens.

The arrangement of the principal pyramids of the Giza Plateau and their similarity to the position of the three stars in the belt of the Orien Constellation.

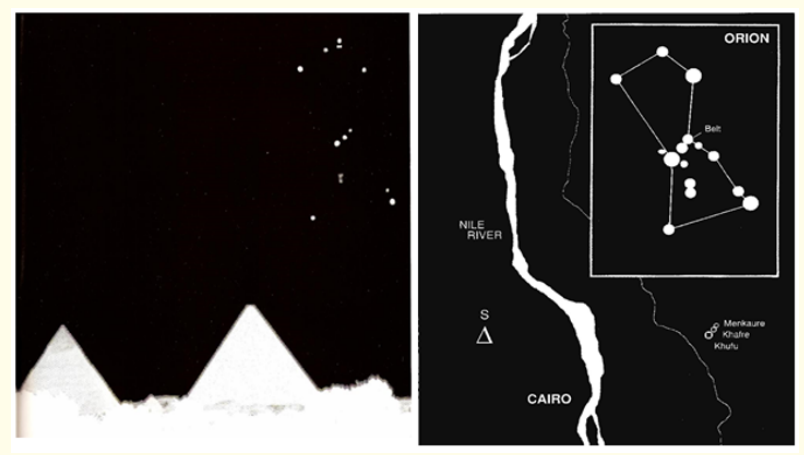

Figure 5

\section{Celestial medicine}

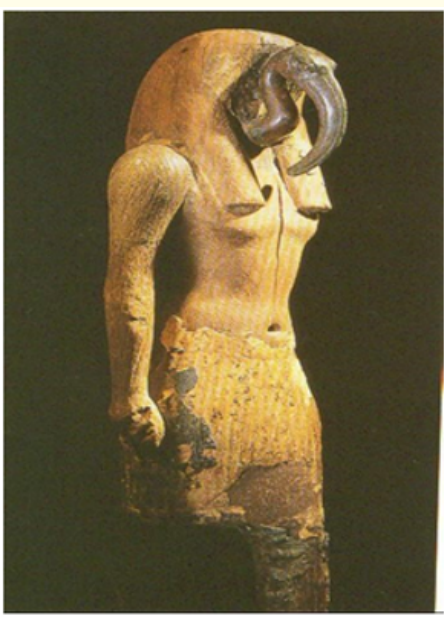

Figure 6
Like the relationship between the Orion constellation and the 3 pyramids of Giza, Egyptian medicine was rooted in the heavens and started with the ibis.

God Thoth (Hermes in Greek), the master of writing, numbers, measurements, time and the universal principals of nature and order of celestial beings.

\section{History of Celestial Medicine in} Ancient Egypt

The history of Egyptian medicine began with Thoth (the Ibis God), Master of Writing, Numbers, Measurements and Time (see plate A). He was later identified as Hermes, the Greek God founder of alchemy, astrology, universal principals of nature and orders of celestial beings, of medicine, and of related sciences (see plate 3). He was also known as Idris (in Arabic). At Hermopolis, he identified the primordial eight as four couples having a single entity: the initial waters and inertia (Naun and Naunet), the spatial infinity (Heh and Henet), the darkness (Kek and Keket), and that which is hidden (Amun and Amunet) or occasionally the void (Niah and Niaut). The qualities of the primordial state have often been compared with the shadowy waters of Biblical Genesis. The lotus, which has its roots in the mud, its stem in the water and its leaves and flowers in the air, receiving celestial light and dew, has always been the symbol of the four elements (see plate 4).

\section{Figure 7}

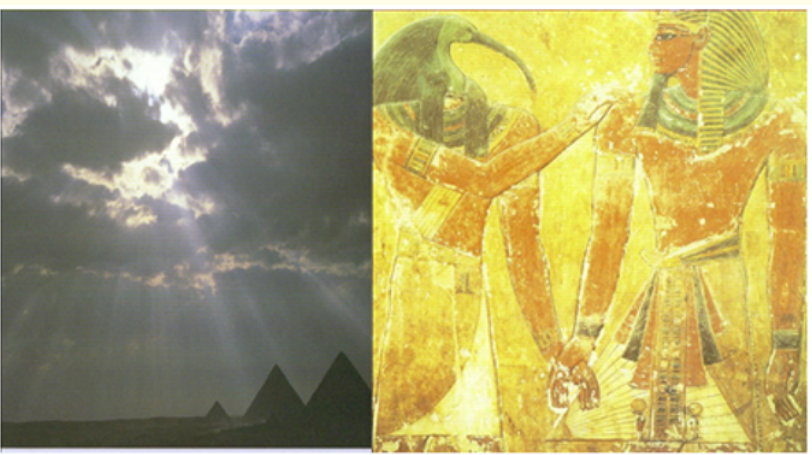

Figure 8

Celestial healing comes through the eye of Horus, the son of Isis and Osiris, and the rays of the sun representing the God Ra. 


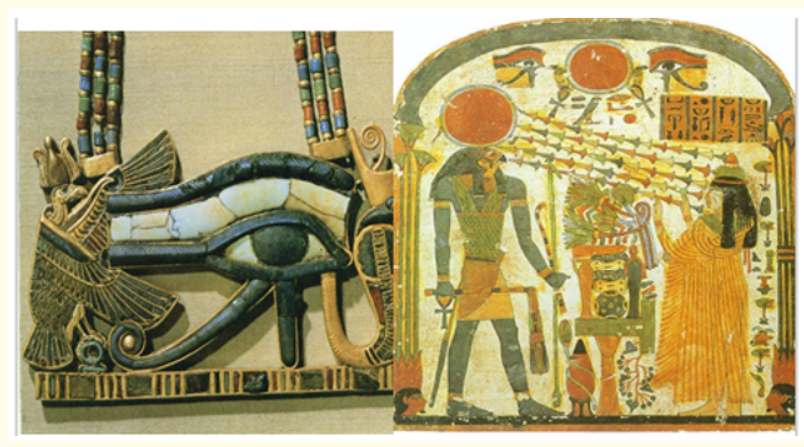

Figure 9

Horus eye and the hieroglyphic fractional notations as used in the prescription of drugs. Ro measures are shown with their equivalent as a fraction of a single heqat (4.5 litres).

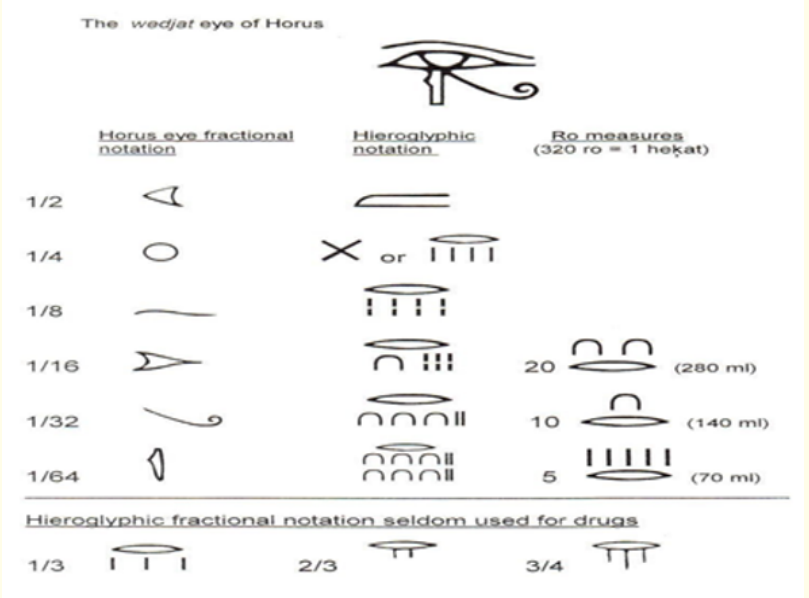

Figure 10

IMHOTEB (he who comes with peace).

The father of Egyptian medicine

- $\quad$ Established the first teaching medical school in Memphis $(2,770 \mathrm{BC})$.

- Treated abdominal, ocular, skin, tongue, intestinal, appendix, dental, surgical, tuberculosis, bladder, arthritis, infertility and appendix cases.

- $\quad$ Prepared many herbal remedies.
- Combined the realms of medicine, priesthood, incantations and magic for the healing of patients.

- Left a rich legacy of knowledge and a library that included the first books in applied medicine and surgery prepared by the son of King Narmer (first Dynasty, 3,100 BC) and impacted medical practice through Greco-Roman times.

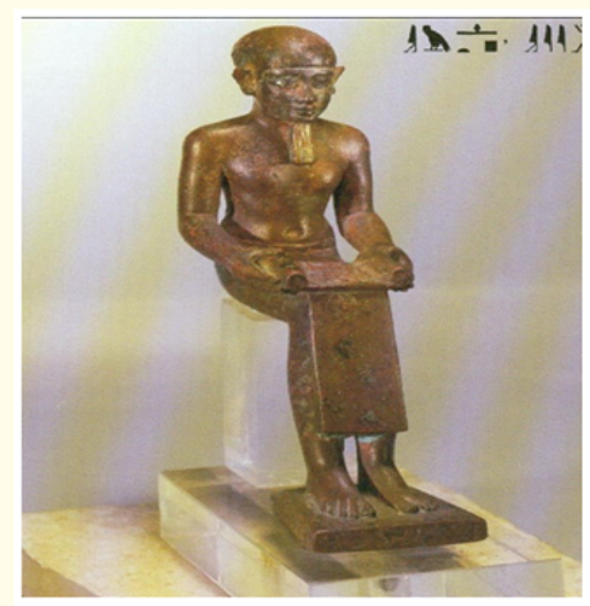

Figure 11

IMHOTEB was also the living incarnation of the perfect man; the grand physician (later deitfied as the Greek God of medicine, Asklepios), architect (the step pyramid complex of Djoser), warrior and politician.

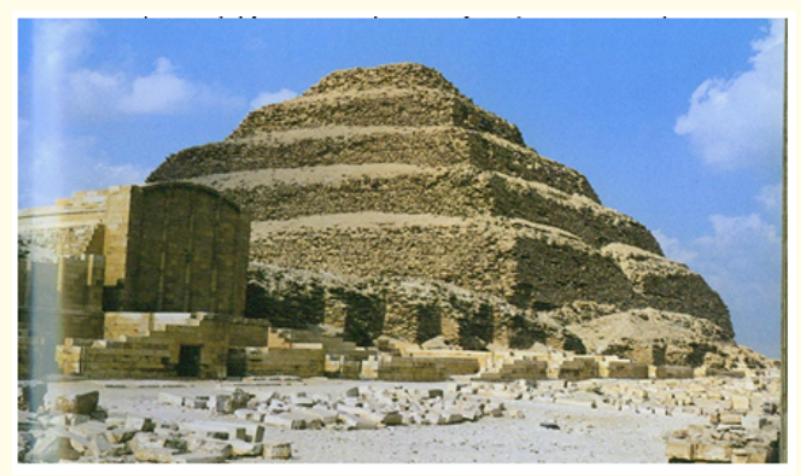

Figure 12 


\section{The Tree of Medical Alchemy}

There are four roots of medical alchemy in Ancient Egypt. 1) Hygiea which deals with hygiene, 2) Panacea which deals with Meteria Medica and therapeutics, 3) Philosophia which deals with practices involving such concepts as placebo effects, and 4) Praxis which involves the developments of various skills comparable to Yoga and Kung Fu.

The system of medical alchemy includes eight branches: 1) Alchemic pharmacy, 2) Internal medicine, 3) Therapeutic diet, 4) Medical astrology, 5) Physical medicine, 6 ) Surgery, 7) Public hygiene, and 8) Internal alchemy.

Figure 13

\section{The Philosophy of Celestial Medicine}

The ancient doctrines of celestial medicine encompass the disciplines of 1) Alchemy of Life, 2) Growth and metamorphosis, 3) Health, death and rebirth, 4) MattHarmonica (harmonious balance), 5) Neters-Entias (lower and higher energies), 6) Correspondences (including the homeopathic law of similars), 7) Signatures (by assignment to the seven celestial signs), and 8) Sympathies and antipathies. The philosophical principles involved employ the concepts of the seven planets, the five elements, praxis (practice) and paradoxes.

\section{Figure 14}

Yuny, one physician from the 19th Dynasty

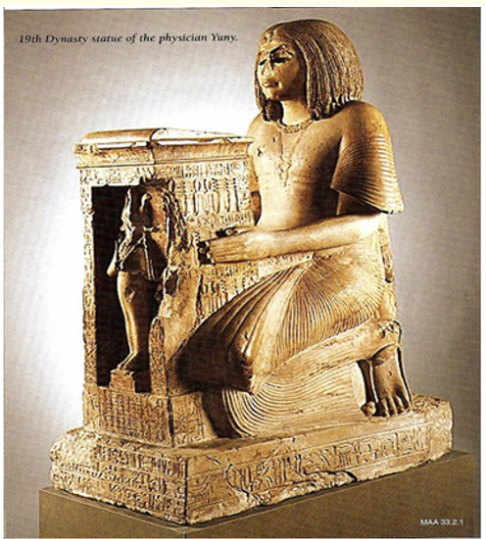

Figure 15
The physician Yuny lived during the early $19^{\text {th }}$ Dynasty. His statue (right) comes from the chapel of the tomb that he built for his father near the modern Egyptian town of Assiut, north of Luxor. Yuny's father was a physician and a priest of Sekhmet, the patroness of physicians. The tomb chapel became a place of pilgrimage for Egyptians seeking help with medical problems.

The physician and training

- In the mystical school of life (Ber Ankh), doctors were trained in medicine, architecture, warfare, administration and religion. Paramedical staff included pharmacists, nurses, midwives, physiotherapists and bandagers. Doctors were always accompanied by assistants. In the healing arts, doctors, priests and magicians were involved.

- Doctors were specialized in gastro-enterology, proctology, dentistry, ophthalmology, inspecting fluids (cardiology) and general practice. Legendary doctors included Djer, Manetho, Amenhoteb-son-of-Hapu, Netjer-hoteb, Sinuhi, Hesi-Ra, Pesesher, Mereruka, Ankh, Gua and Seni, among others.

- Medical schools started in the Old Kingdom and were associated with temples. These included Imhoteb's School in Memphis, Midwifery School in Sayes in Delta, School of Surgery in Thebes, and Oun Medical Institute in Heliopolis where principles and practice of medicine, and specializations were taught.

Types of physicians

\begin{tabular}{|c|c|c|c|c|}
\hline & $\begin{array}{l}\text { OLD KINGDOM } \\
\text { AND FIRST } \\
\text { INTERMEDINE } \\
\text { PERIOD } \\
\end{array}$ & $\begin{array}{l}\text { YIIDDLE } \\
\text { KINGDOM }\end{array}$ & $\begin{array}{l}\text { SECOND } \\
\text { INTERMEDLATE } \\
\text { PERIOD AND } \\
\text { NEW KINGDOM }\end{array}$ & $\begin{array}{l}\text { THIRD } \\
\text { INTERMEDLATE } \\
\text { PERIOD AND } \\
\text { LATE PERIOD } \\
\end{array}$ \\
\hline ophthalmologist & $7^{*}$ & - & - & $2^{*}$ \\
\hline gastro-enterologist & $2^{*}$ & - & - & $1^{*}$ \\
\hline proctologist & $2^{*}$ & - & - & - \\
\hline dentist/doctor & $3^{*}$ & - & - & 1 \\
\hline dentist only & 2 & - & - & - \\
\hline swnw - supervisor of butchers & 3 & - & - & - \\
\hline \multicolumn{5}{|l|}{ inspector of the liquids in the } \\
\hline netnetet & $2^{*}$ & - & - & - \\
\hline total involved in one or more & & & & \\
\hline specialties & $16^{*}$ & - & - & $3^{*}$ \\
\hline
\end{tabular}

Figure 16

The false door of Ir-en-akhty (first intermediate period) showing the modern equivalents of his remarkable range of medical specialties practiced in the great house (palace). 


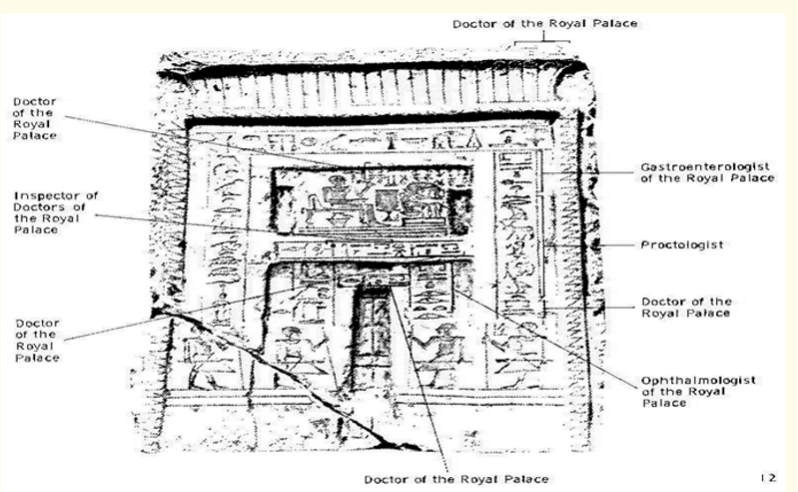

Figure 17

A physician's ointment jar (left) and the Metternich Stela (right) depicting Horus controlling poisonous and biting animals (originally set up in a temple in Heliopolis) to provide healing via poured magic water
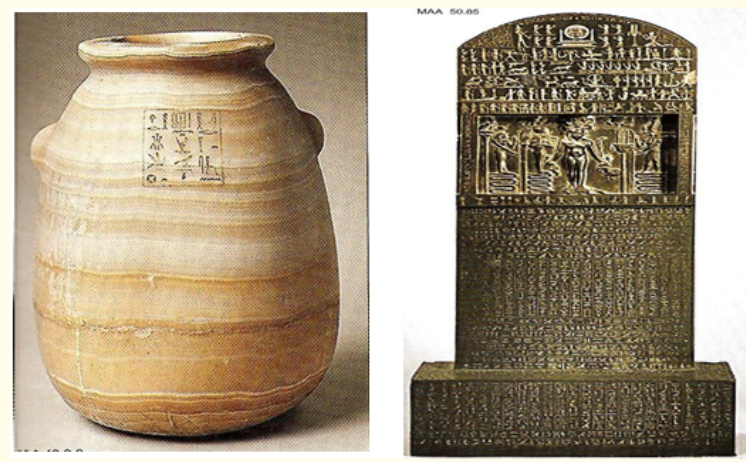

Figure 18

The medical papyri are the most important sources of information about Ancient Egyptian medicine. They fulfilled the same role as medical texts today and were taught in the medical School of life.

\begin{tabular}{|c|c|c|c|}
\hline TITLE & LOCATION & $\begin{array}{l}\text { APPROXIMATE } \\
\text { DATE OF COPY }\end{array}$ & CONTENTS \\
\hline Edwin Smith & New York & $1550 \mathrm{BC}$ & surgical, mainly trauma \\
\hline Ebers & Leipzig & $1500 \mathrm{BC}$ & general, mainly medical \\
\hline $\begin{array}{l}\text { Kahun } \\
\text { (gynaecology) }\end{array}$ & $\begin{array}{l}\text { University College, } \\
\text { London }\end{array}$ & $1820 \mathrm{BC}$ & gynaecological \\
\hline Hearst* ${ }^{*}$ & California & $1450 \mathrm{BC}$ & general medical \\
\hline $\begin{array}{l}\text { Chester } \\
\text { Beatty VI }\end{array}$ & вм 10686 & $1200 \mathrm{BC}$ & rectal diseases \\
\hline Berlin* & Berlin & $1200 \mathrm{BC}$ & general medical \\
\hline London* & вм 10059 & $1300 \mathrm{BC}$ & mainly magical \\
\hline Carlsberg VIII & Copenhagen & $1300 \mathrm{BC}$ & gynaecological \\
\hline $\begin{array}{l}\text { Ramesseum } \\
\mathrm{II}, \mathrm{IV}, \mathrm{V}\end{array}$ & Oxford & $1700 \mathrm{BC}$ & $\begin{array}{l}\text { gynaecological, } \\
\text { ophthalmic and } \\
\text { paediatric }\end{array}$ \\
\hline $\begin{array}{l}\text { London and } \\
\text { Leiden }\end{array}$ & $\begin{array}{l}\text { BM } 10072 \\
\text { and Leiden }\end{array}$ & AD 250 & $\begin{array}{l}\text { general medical } \\
\text { and magical }\end{array}$ \\
\hline Crocodilopolis & Vienna & AD 150 & general \\
\hline Brooklyn snake* & Brooklyn & $300 \mathrm{BC}$ & snake bite \\
\hline
\end{tabular}

Figure 19

The EBERS papyrus

$20 \mathrm{~m}$ long, found in 1862; written in $1536 \mathrm{BC}$ in hieratic.
Includes the diagnosis, treatment, and prognosis of 27 surgical cases, eye disease and dental issues: dental surgery, gum disease, fillings, dental hygiene and treatments.

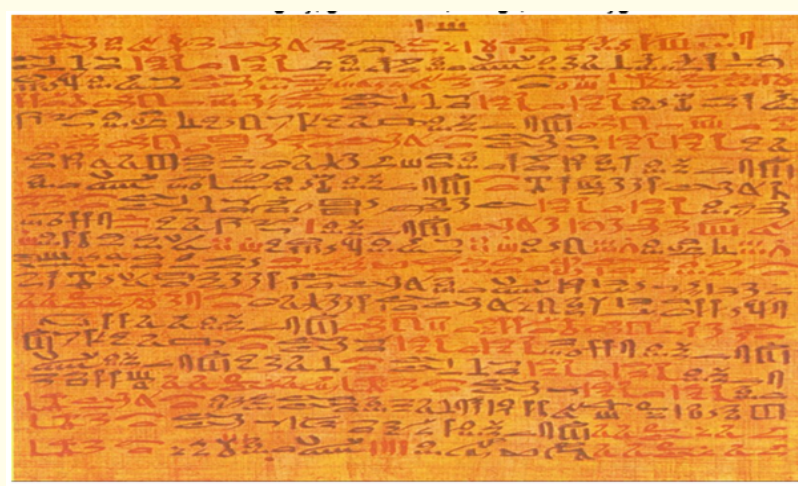

Figure 20

Discussion of the relationship between proper nutrition and public health in the ein Singer Nutritional papyrus ends with the following generic recommendations and perspectives:

- Control of excesses is the heart of wisdom.

- Vegetables and Notron salt are the better foods.

- Diseases inflict those that eat excessively.

- He who eats too much bread will have many sicknesses.

- He who drinks too much wine will lose balance.

- $\quad$ Excessive eating will also affect the limbs.

- He who practices a balanced life style will have a healthy body.

- Disease does not burn out those who eat moderately.

- $\quad$ Likewise, poverty will not burn out those who buy wisely.

This papyrus also advises about treating wounds and the importance of health education and social, psychological, and emotional balance. Doctors who follow the book but do not succeed are safe; not charged or punished.

Contents of a general medical papyrus

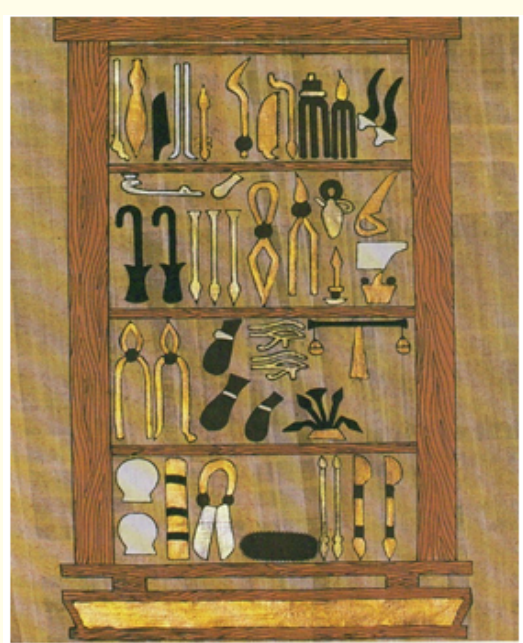

Figure 21 
An introductory general section deals with medication for fever and a prescription book for drugs and activities followed by sections dealing with:

- $\quad$ Injuries and wounds

- $\quad$ Ailments of the head

- Growths, swellings and itching

- Diseases of internal organs

- $\quad$ Respiratory illnesses

- Women's ailments

- Beauty treatments and hair care

- Household products and prevention of pests

- Drawings of doctors and surgical tools (right)

- Instruments

The diagnoses in the papyri had no rigid scheme but usually developed along five points and involved good knowledge of pathology and anatomy of body structures.

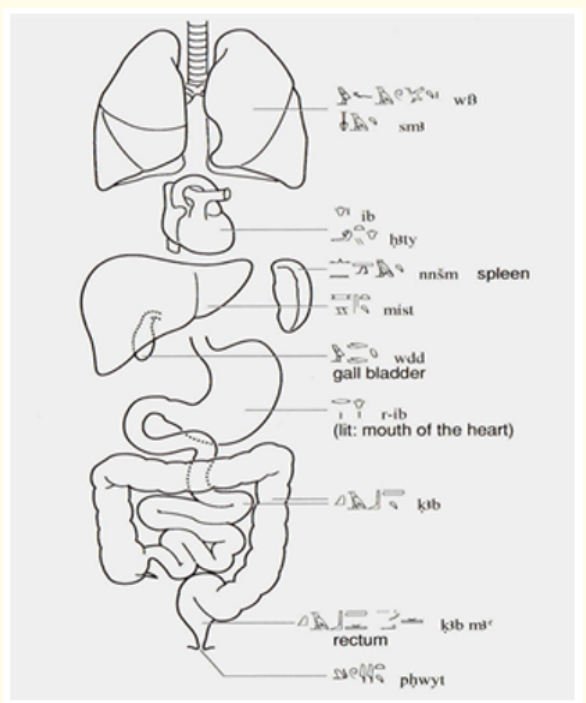

Figure 22

1. The title

2. The examination (inspection) which involved questioning, probing with hands and smelling

3. Naming the type of illness

4. The treatment and instructions of a prescription, e.g., details about medications and use of honey and beer to administer them, activities, therapies and bandages.

5. Description of the case, diagnostic and treatment procedures, conclusions and prognosis.
Recto, column 13: case 39. A chest infection.

- Title: Practices for an eruption with flattened head in his chest.

- Examination and prognosis: If you treat a man for an eruption with flattened head in his chest and you find risings having formed with pus, making a rash, while there is much warmth there and your hand finds it, then you say it is an ailment I will handle.

- Treatment: You have to sear him on his chest, on that eruption that is on his chest. Treat him with a wound treatment. You should not wait for it to open by itself: it is not good for his wound.

- Explanation: As for "an eruption with flattened head in his chest", it means that things are continually swollen and spread out on his chest because of his injury, having made pus and something red on his chest. That is to say, it is like things that have been scratched and create pus.

- $\quad$ Note: This superficial abscess it treated by incision and drainage, similar to what a modern surgeon would do. The "searing" was most probably done with a heated metal rod, the heat from which would control any bleeding analogous to modern cautery.

Other examples of anatomical knowledge

Eye diseases, ex., blindness, Glaucoma, night blindness, cataract, allergies, and Trachoma, were treated with natural remedies, ointment and oil blends and metals like Malachite (copper carbonate) and kohl (antimony sulphide and other compounds) known since $3000 \mathrm{BC}$.

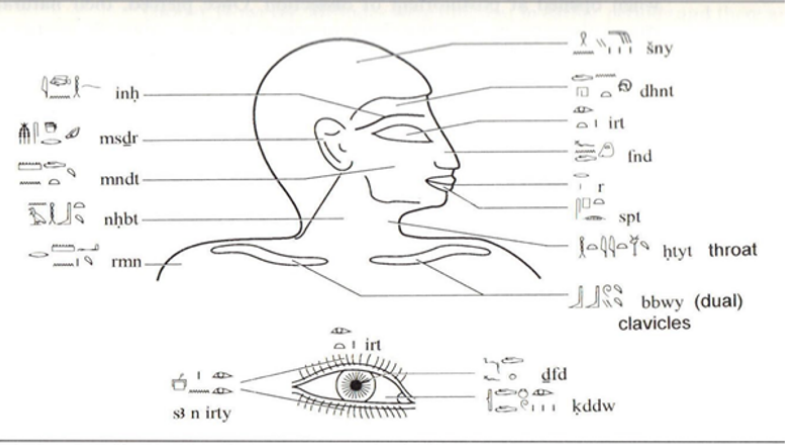

Figure 23 
The lateral aspect of the skull

This has special relevance to the Edwin Smith papyrus, cases $1-27$.

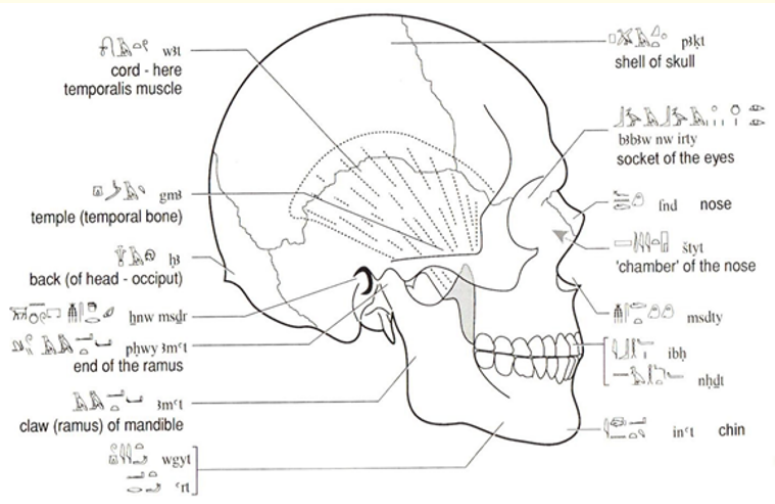

Figure 24

The Celestial Anatomy and Physiology

This ancient medical school deals with the higher consciousness of the structural-functional relationship tion. It includes nine disciplines 1) "Ba-Phoenix-SoulSulphur- Body" addresses the spiritual or psychic force of the being (a bird form with human heal) that outlasts death in the context of male action of iron and gold. Mars and the Sun. "O you who cause the perfected souls to draw to the House of Osiris, may you cause the excellent soul of the deceased to draw near with you to the House of Osiris" (see plate 6), 2) "Ka-Celestial-Spirit-MercuryBody" addresses the life force of the other self (the double) embodying intellectual and spiritual power representing the potency of the copper and mercury of Venus and Mercury, 3) "Knat-Elemental-Physical-Salt-Body," 4) "Ankham-Archeus-Vitality" from Ankham meaning Life, a flower garland that gave the dead the divine life force, 6) "Naat-Harmonia" or the force of harmonious balance, from " blockage or conflict between higher and lowg energies, 7) "Planetary Constitution" and individual constitution as well as the constitution of remedies at the celestial level; agreement of similars or disagreement spell health or disease, 8) "Diagnosis, Case Taking, Prognosis," and 9) "Therapeutics and Case Management" (see medical papyri following).

Figure 25

\section{Internal Alchemy}

One of the most interesting and intriguing concepts of celestial medicine in Ancient Egypt are those internal alchemy that deal with the various levels of body consciousness to attain harmony and balance. The seven jewels of internal alchemy are 1) Maat life style which is associated with Saturn, 2) Maat arts-Venus, 3) Maat diet-Jupiter, 4) Maat medicines-Mercury, 5) Maat exercises-Mars, 6) Maat dreaming-Moon, and 7) Maat meditation-Sun.

Figure 26

\section{Constitutions of Egyptian Medicine}

The seven constitutions of Egyptian medicine are those reflecting the essence of the seven planets, the Moon (Monday), Mercury (Wednesday), Venus (Friday), Sun (Sunday), Mars (Tuesday), Jupiter (Thursday), and Saturn (Saturday). Within the constitution of each of the planets lies the similar constitutions of the physical and spiritual body, imbalances and diseases, and remedies (law of similars) at the various levels of consciousness. For example, the constitution of the sun (gold) includes aurum, aspiration, heart, circulatory system, plasma, blood, pituitary, eyes, vision, calmness, pride, ego, psora, meditation, yang, Leo, fire, and sulphur.

The seven planets are divided into 24 hour day. A planetary hour $=3$ hours and 26 minutes. The first planetary hour begins at 3:26 am to 6:52 am each day, and is named after the ruling planet of that day, e.g., on Sunday, the Sun rules the first planetary hour of the day.

\section{Figure 27}

The power of healing vested in the magical eye of Horus provided a protective power for such procedures as delivery. The goddess Isis is seen in a crouching position on a delivery stool.
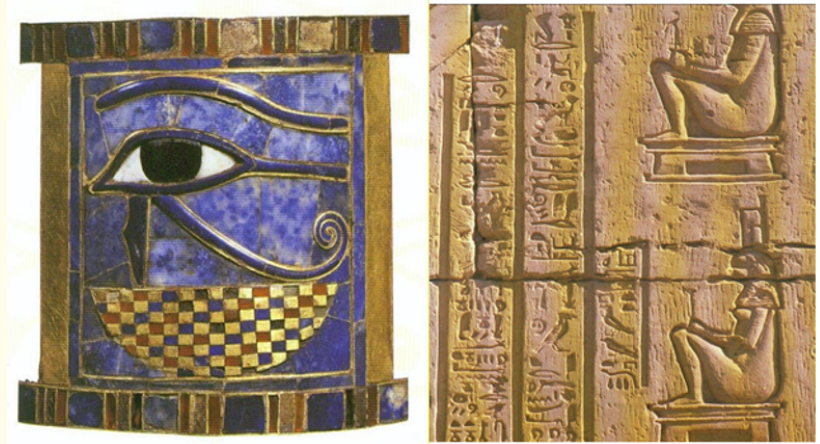

Figure 28

\section{Concepts of Pathology}

It was apparently easier to understand the causation of the more readily observable traumas than those related to internal medical disorders such as heart disease or tumors. Traumas, especially those related to industrial accidents, warfare and animal bites were well documented in the Edwin Smith papyrus, at least 1000 years before the Hippocratic time of medicine. There is a rich vocabulary to describe injuries with precise definitions of their meaning. The soft tissue (flesh) wounds (webenu or kefet) and fractures (heseb) are only known in the Edwin Smith papyrus. Injuries to the joints include dislocations (wenekh) and sprains (nerut). Snake bite and scorpion sting are especially contained in the Metternich Stela. Egyptians undoubtedly recognized the toxic substance (metit) injected by the animal as the cause of associated pain and breathing difficulties.

Figure 29 


\begin{abstract}
Diseases and Disorders
Two major categories are recognized. Parasitic and infectious diseases are separated from internal and constitutional disorders. Parasitic diseases have had a major public health impact in Ancient Egypt. Worm parasites are recognized by recovering their calcified eggs from mummies, especially when unembalmed. Measures of avoidance are often repeated in ancient text. The more common parasitic and infectious diseases documented include schistosomiasis, drucunculiasis, filariasis, strongyloidiasis, ascariasis, taeniasis, malaria, tuberculosis, leprosy, tetanus, and plague. Sepsis and abscesses, osteomyclitis, poliomyelitis and smallpox have also been reported. Pain (wekhedu) (to suffer) has also been repeatedly addressed. Wekhedu was said to afflict many organs, including the belly, skin, mouth, chest, back, heart, head, eyes, and teeth. Many remedies were to drive out or to ward off wkhedu. The wkhedu can "pull through" (hebheb) or pass from one part of the body to another. Each month for three successive days Egyptians purged themselves, for their health sake, with emetics and enemas, in the belief that diseases came from the food one eats. The aaa-disease (the discharging of the phallus) refers to blood in the urine which is caused by schistosomiasis (the hereret worm).
\end{abstract}

\section{Figure 30}

Diseases and disorders of the internal organs included heart diseases (see The Body above), atherosclerosis and calcification of large arteries. There's also a possible reference to ischaemic heart disease in Ebers p. 191. Lung and pneumonia were also diagnosed. Remedies to drive out cough (seryt) from the lungs (wefa and sema) are found in Ebers p. 321 and Berlin pp. 29-38. Gastro-intestinal illnesses are commonly cited especially in the Book of the Stomach. Eleven paragraphs mention "obstruction" in the title. Fecal impaction was not uncommon. Herodotus mentioned that the Egyptians were obsessed with their bowels. Ebers P. 203 states "you should then make for him a powerful remedy of oil in order that it All medication for constipation were taken orally. A com. mon remedy was to "purge the intestine by a drink: sweet beer left overnight with notched sycamore fig which has dried" (Ebers p. 207). The urinary tract has special sections in Ebers (PP. 261-283), Berlin and Hearst papyri. Remedies were noted to eliminate such conditions as blood in the urine, polyuria (related to diaberes?), Cystitis, irritable nervous system were largely related to the description of neurological consequences of injuries. Facial nerve paralysis (Bell's palsy) has also been diagnosed. Hernias and hydroceles, pains and aches, migraines, disorders of the ear, nose and skin as well as aging have been documented. The Ancient Egyptians were quite conscious of
the aging process. Upon his return to Egypt as an older

\section{Figure 31}

Polio (case of Roma, $19^{\text {th }}$ dynasty) and dwarfism (The Sonb family, $4^{\text {th }}$ dynasty).

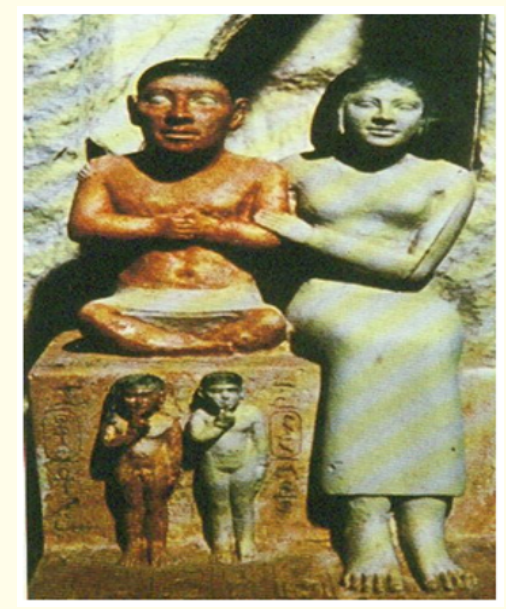

Figure 32

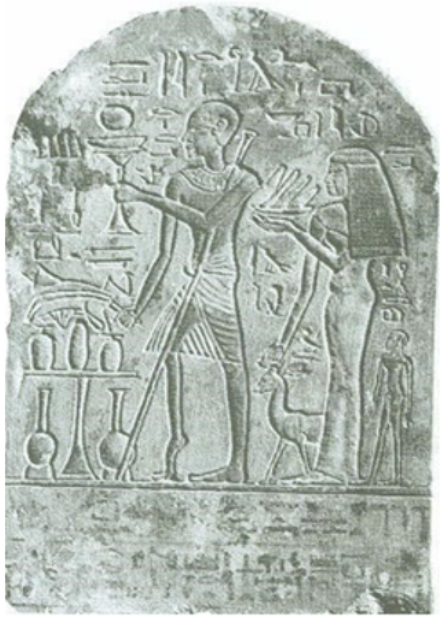

Figure 33

Documentation of an epidemic that killed the son (lower right) of Ramses III shown with the Goddess Isis in the Palace of Thebes.

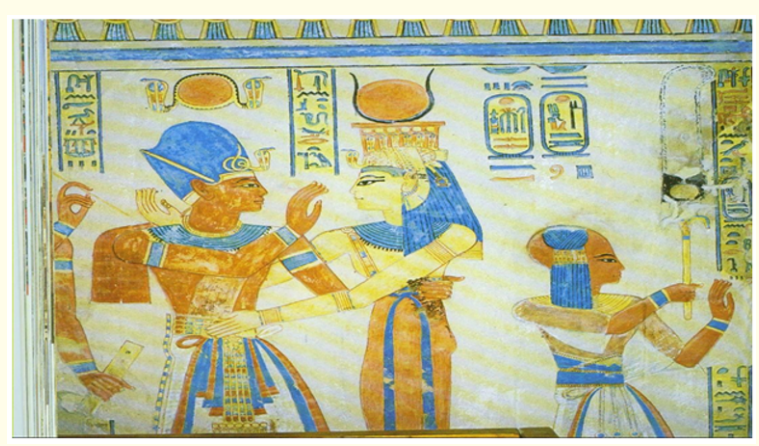

Figure 34

A case of spinal tuberculosis (Pott's disease) in Nesparehan from the cache of 44 priests of Amun from the $21^{\text {st }}$ dynasty. The lateral view shows the acute angulation of the spine (kyphosis); the anterior view shows an abscess in the lower part of the right abdomen.

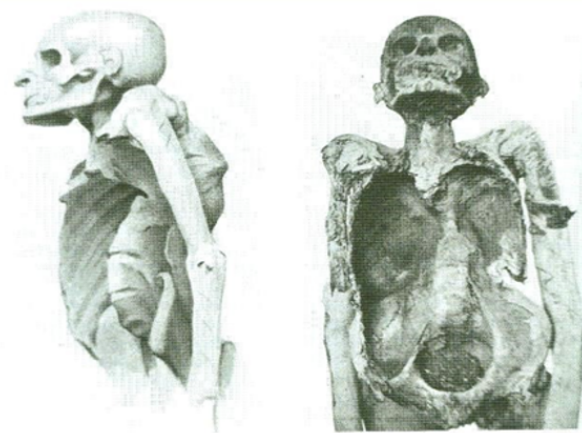

Figure 35 
"Brittle bone" disease is documented from the coffin and the bones of this child.

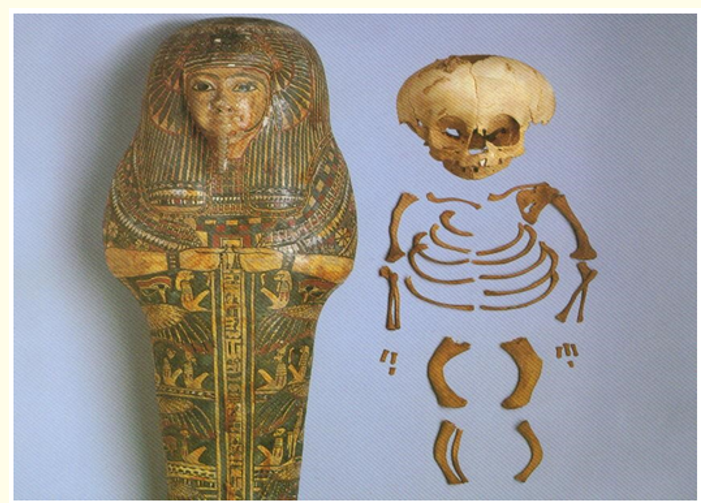

Figure 36

Treatment of a stone cutter, who received a splinter in the eye while working, by an eye doctor. Egyptian ophthalmologists were highly regarded especially by foreign rulers.

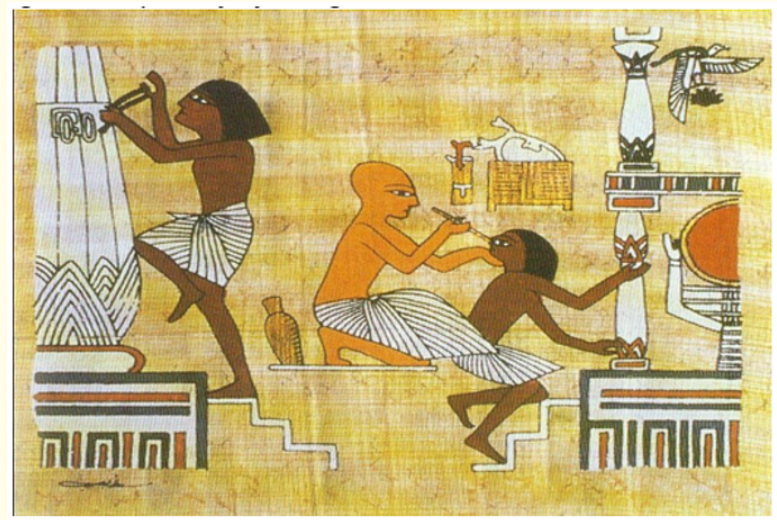

Figure 37

Evidence of the parasitic fluke causing schistosomiasis was revealed from test samples of skin from this naturally desiccated body of an adolescent (c.3200 BC).

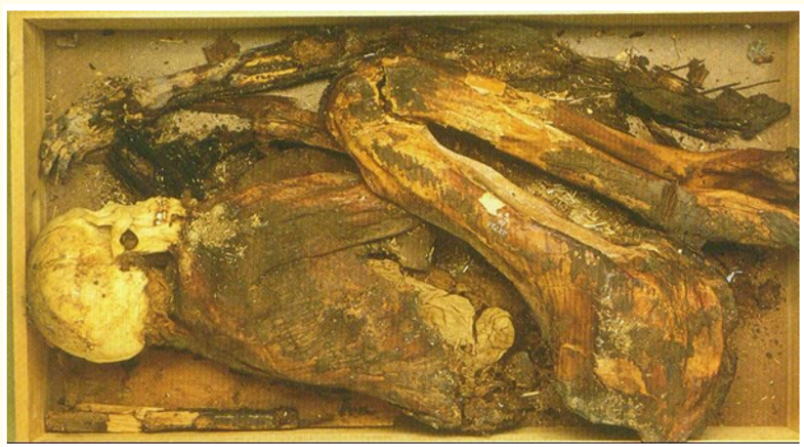

Figure 38

Identifiable remedies for specific intestinal parasitic worms especially roundworms (Ascaris) (hefat) and tapeworms (Taenia) (pened).

$76 \%$ of Egyptian remedies match the British Pharmaceutical Codex of 1973.

\begin{tabular}{|c|c|c|}
\hline \multicolumn{2}{|c|}{ HERBAL REMEDIES } & \multirow{2}{*}{$\begin{array}{l}\text { MINERAL REMEDIES } \\
\text { H P salt of Lower Egypt }\end{array}$} \\
\hline H P & acacia leaves & \\
\hline & barley & P natron \\
\hline $\mathrm{P}$ & bread & P red ochre \\
\hline HP & carob (djaret) & H malachite \\
\hline $\mathbf{P}$ & conyza (innek) & P desert oil \\
\hline $\mathbf{P}$ & cumin & \\
\hline HP & cyperus grass & ANIMAL REMEDIES \\
\hline HP & dates & H P honey \\
\hline $\mathbf{P}$ & earth almonds (sheny-ta) & P white oil \\
\hline $\mathrm{P}$ & juniper berries & Pox fat \\
\hline $\mathrm{P}$ & pine oil & $P$ goose fat \\
\hline н P & sedge & \\
\hline H & kaa part of sycomore & VEHICLES \\
\hline $\mathrm{H}$ & kaw sycomore figs & H P beer \\
\hline H & roots of pomegranate & P milk \\
\hline HP & wormwood/absinthe & $\mathrm{P}$ wine \\
\hline
\end{tabular}

Figure 39

Evidence of the parasitic fluke causing schistosomiasis was revealed from test samples of skin from this naturally desiccated body of an adolescent (c.3200 BC). 


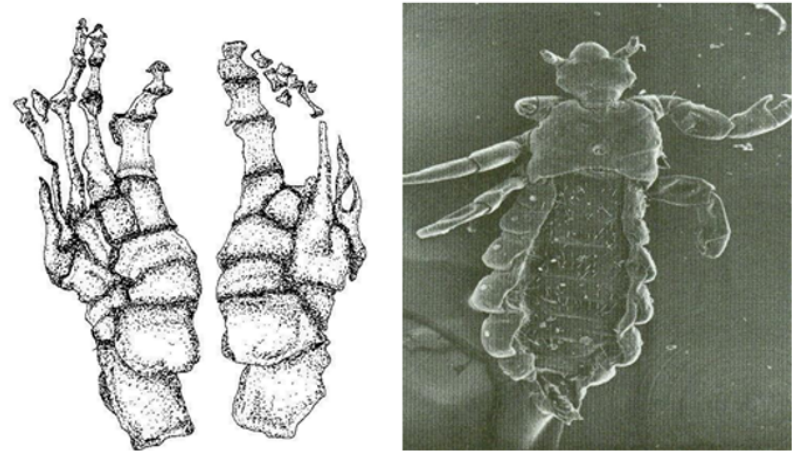

Figure 40

Egyptians often used essential oils for treatment of a wide variety of maladies. The gold container (left) and the alabaster container (right) of Tutankhamun contained essential oils.
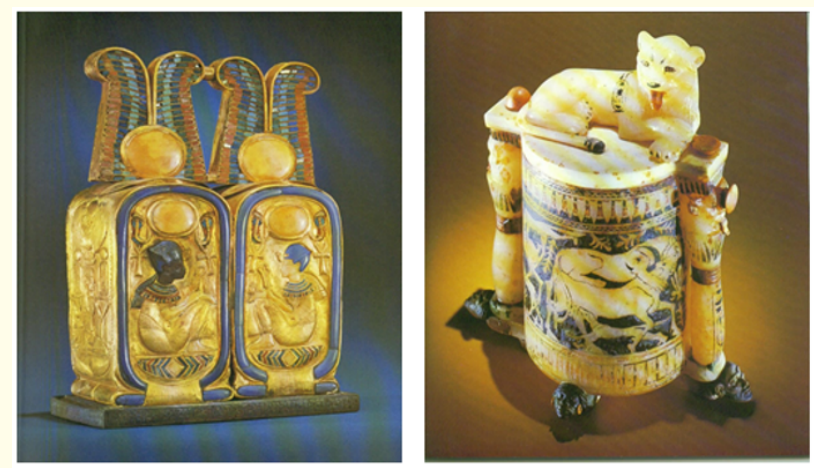

Figure 41

Symbols of health, life and power included the Ankh (key of life) and the cobra; from Tutankhamun. A hand mirror and a cobra with dilated hood made of gilded wood and quartz eyes are shown.
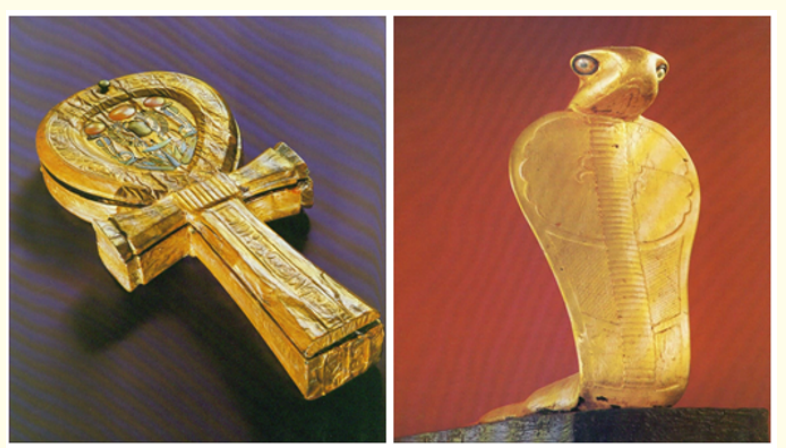

Figure 42
Incantations and magic were often invoked along with medical and religious practices and rituals. This alabaster chalice represents a single bloom of the white lotus is used as a "wishing cup" from its inscription to Tutankhamun.

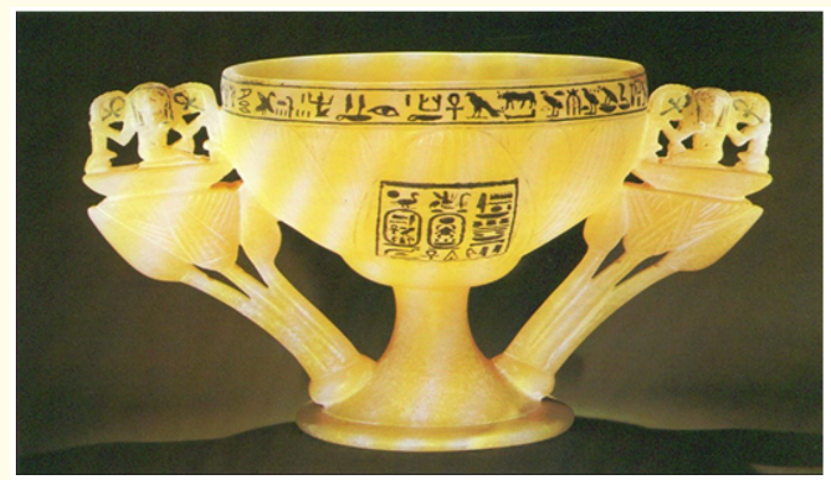

Figure 43

\section{The Remedies}

"Another remedy to drive out the hefat-worm (Ascaris): afa (wild letruce) wormwood/ absinthe (sam), vegetable mucus (hesa); mix as one thing and eat. He will then evacuate (wesesh) all worms (djedfet) which are in his belly." (Ebers p. 64). "Another remedy to kill the pened- worm (Taenia): khetpart of the kesbet-tree, 5 ro, strong beer, 20 ro; cooked, strained and drunk immediately." (Ebers p. 72). Remedies for other parasites included acacia leaves, juniper berries, cumin, garlic, dates, pine oil, roots of pomegranate as well as honey, white oil, natron salt, beer, milk and wine. Some remedies taken internally for disorders of the urinary system include honey, cyprus grass, beer, grapes. juniper berries, ochre and fresh dates (Ebers). Moringa oil, juniper berries, ochre and fresh dates (Ebers). Moringa oil, mended to eliminate heat in the bladder when suffering from retention of urine occurs (Ebers).

Some drugs used for treatment of coughing (seryt) included alum, fat, acacia gum, acacia leaves, cumin, pounded dates, figs, honey, milk, salt of lower Egypt, water of yeast wheat, wine, wor but unidentifiable products.

\section{Figure 44}

The following is a brief accounting of major herbs and their uses in Ancient Egyp: A cir promotes hair growth, a vaginal suppository. Acacia nilotica (Acacia): kills worms, tanning, wound Ciseases, swollen legs. Alium cepa (Onion): ear treatment, snake repellant, stops menseruating. Allives for warts on gen cye trear. ache and skin diseases. aphirodisiac. Aloe vera (Aloe): for eye and skin diseases, diges-

Anethum graveolens (Dill: headache, mouth rinse. Apizem graveolens (Celery): teeth and tongue burns, swollen limbs and stomachache. Apium petroselinum (Parsher): stomachache.

Artemesia absinthium (Wormwood): expels worms, for pain in arms, skin inflammation Cannabis sativa (Hemp): Glaucoma and eye treatment, as enema. Carthamus tinctorizes (Safflower): as Kohl, for
bandages, poisonous stings.

Figure 45 
Ceratonia siliqua (Carob mee) pod: carob beer, vermifuge, for digestive disorders, inflamed

Cicer arietinum (Chick-pea): stimulates milk

Cichorium intybus (Chicory): diuretic and laxarive, treatment of jaundice, headache, live

Cinnamonizem zeylanicum (Cinnamon): stimulant, digestive, antiseptic, in perfume, in suppository

Citrullus Lanatus (Water melon): constipation.

Cordia myxa (Egyptian plum): laxative, for pulmo-

Coriandrum sativum (Coriander): for rheumasites, stomach ailments and burns, expels fever, antidote for poison.

Cucumis melo (Melon): for heart, stomach and anus ailments, and inflamed legs.

Cucumis melo sativus (Cucumber): for milk pro-

. Cumin cyminum (Cumin): for indigestion and pain, headache, as post-enema trearment.

Figure 46

Ensete rentricosum (Wild banana): as enema. aphrodisiac.

Ficus carica (Fig): for constipation, belly, lung and heart disease, hemorrhoids and skin inflammation. Ficus sycamorus (Sycamore fig): for constipation, and swellings, in cooling bandage, expels worms. Foeniculum vulgare (Fennel): for eye ailments, Foeniculum vulgare

Glycyrrbiza glabra (Liquorice) root: as a laxative, anti-inflammatory, for coughs, bronchitis asthma, gastric ulcers, wounds, eye lotion and vomiting. prognosis.

Juniperus phoenicea (uniper): fumigant, antiaxarive, raperic, stimulant and carminative, asthma and headache, as vaginal suppository to induce childbirth, body massage.

Lactuca sativa (Letruce): eye poultice, for bellyache, worms, hair growth and cough, vermifuge. tive, expels fever.

Figure 47
Papaversomniferum (Commonpoppy): Aphrodisiac, for inflamed or bruised skin, sedative for colic, cough and crying child, as morphine.

Phoenix dactylifera (Date palm): beverage, for swelling of limbs, cough and sneezing, laxative, vermifuge.

Pimpinella anisum (Aniseed): Carminative and digestive, for cough, headache, toothache and stomachache, milk stimulant, weakly diuretic.

Piper nigrum (Black pepper): stomachache, carminative, antibacterial, insecticide, diaphoretic, stimulant, induces abortion.

Prunus dulcis (Almond): oil, as laxative, for massage. Punica granatum (Pomegranate): for fertility, expelling worms, dysentery, diarrhea, stomachache, eye, skin, ear ailments, as enema.

Raphanus sativas (Radish) oil: for skin diseases. Ricinus communis (Castor) oil: purgative and emollient, for limb and gland ailments.

Rosemarinus officinalis (Rosemary): digestive and antiseptic, for tired limbs, headache, hair and skin care.

Figure 49
Hordeum vulgare (Barley): with emmer for birth Lepidum sativum (Cress): for runny eyes, laxa-

Salix suberrata (Willow): appetite stimulant, antiseptic, cooling bandage for inflammation, burning/aching blisters and skin diseases.

Sesanum indicum (Sesame): nutritive, laxative, emollient, haemorrhoid treatment, lactation stimulant.

Sinapis alba (White mustard): for swelling, cough, jaundice, stomach ailments, toothache, flatulence and aching temples, as enema.

Thymus sp. (Thyme): antiseptic, antispasmodic, carminative, for headache, intestinal, lung and stomach ailments.

Trigonella foenumjgraecum (Fenugreek): for rejuvenation, lactation and childbirth, stimulant in vaginal suppository, anti-inflammatory, fever treatment.

Vigna sinensis (Bean): for constipation, aphrodisiac, as enema.

Vitis vinifera (Grape): vine for appetite, cough and fever, laxative, wine, vermifuge, as breast lotion.

Figure 50

Commonly used spices of medicinal use in Ancient Egypt.

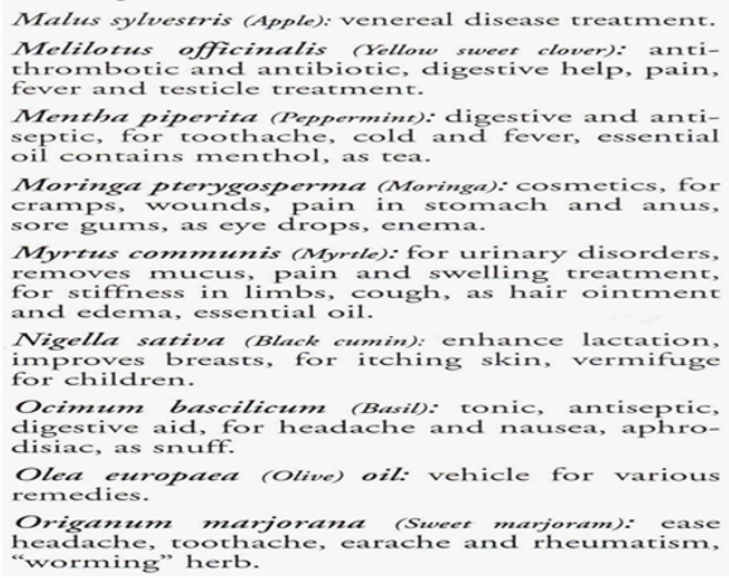

Figure 48

\begin{tabular}{|c|c|c|c|c|}
\hline $\begin{array}{l}\text { NOMMON } \\
\text { NAME }\end{array}$ & LINNEAN NAME & $\begin{array}{c}\text { EGYPIIAN } \\
\text { NAME } \\
\end{array}$ & $\begin{array}{l}\text { FRST RECORDED USE } \\
\text { AS FOOD }\end{array}$ & MEDICAL USE \\
\hline aniseed & Pimpinella anisum & inset?? & Pliny & considerable ${ }^{1}$ \\
\hline cinnamon & $\begin{array}{l}\text { Laurus cinnamonum } \\
\text { (Cinnamonum zeylanicum) }\end{array}$ & ti-shepes & Twentieth Dynasty ${ }^{2}$ & considerable \\
\hline conyza & $\begin{array}{l}\text { Erigeron aegypticus } \\
\text { (Conyza aegypticus) }\end{array}$ & innek?? & uncertain & considerable ${ }^{3}$ \\
\hline coriander & Coriandrum sativum & shaw & Eighteenth Dynasty ${ }^{4}$ & considerable \\
\hline cumin & Cuminum cyminum & tepnen & Dynasty $y^{2,4}$ & considerable \\
\hline & Anethum graveolens & imset & Eighteenth Dyn & occasional \\
\hline fenugreek & $\begin{array}{l}\text { Trigonella foenum- } \\
\text { graecum }\end{array}$ & hemayt & unclear & extensive \\
\hline safflower & Carmathus tinctorius & kata?? & unclear & \\
\hline & Thymus acinos & innek?? & unclear & considerable ${ }^{4}$ \\
\hline \multirow{2}{*}{\multicolumn{3}{|c|}{$\begin{array}{l}\text { First recorded use as food depends both on texts and on } \\
\text { archaeological findings (Darby, Ghaliounghui and Grivetti, } \\
\text { 1977). Accounts of medical use are based on the appearance } \\
\text { of the Egyptian word in the medical texts (Grumdriss vi, 1959). }\end{array}$}} & \multicolumn{2}{|c|}{$\begin{array}{l}2 \text { Presented by Ramses IIt to the gods on many occasions, but } \\
\text { found earlier in non-specific contexts. }\end{array}$} \\
\hline & & & \multicolumn{2}{|c|}{$\begin{array}{l}3 \text { Medical use is based solely on the word innek, which cannot } \\
\text { be translated with any certainty. }\end{array}$} \\
\hline \multicolumn{3}{|c|}{$\begin{array}{l}\text { I This is based on the word insel, for which the meaning is } \\
\text { still uncertain. }\end{array}$} & \multicolumn{2}{|c|}{4 Found in tomb of Tutankhamun (Hepper, 1990). } \\
\hline
\end{tabular}

Figure 51 


\section{Epilogue: From the Book of the Dead}

I would like to conclude by quoting a passage from The Egyptian Book of the Dead (the correct name is actually The Book of Coming Unto the Day). "Thou art the lord of heaven, the lord of earth, the creator of those who dwell in the heights (6) and those who dwell in the depths. Thou art the One god who came into (7) being in the beginning of time. Thou (12) art crowned with a heavenly form, the Only one... O thou mighty youth, thou everlasting son, self-begotton, who didst give thyself birth, (13) $O$ thou mighty One, of myriad forms and aspects, king of the world, Prince of Annu, lord of eternity and ruler of the everlasting... Thou art unknown and canst be searched out....; thou art (16) the Only one....

The text of this book is in the papyrus of Ani, one of the largest, most perfect and best preserved and illustrated papyri known. It was acquired by the Trustees of the British Museum in 1888. It dates to the second half of the Eighteenth Dynasty, 1500 to 1400 years before Christ. It proclaims the resurrection of a spiritual body and the immortality of the soul as already been established by earlier ancestors.

Figure 52

Volume 2 Issue 11 November 2019

(c) All rights are reserved by Omar M Amin. 